\title{
Protection of Tomato, Lycopersicon esculentum from Wilt Pathogen, Fusarium oxysporum f. sp. lycopersici by Arbuscular Mycorrhizal Fungi, Glomus sp.
}

\author{
S. Merina Prem Kumari ${ }^{1} *$ and B. Jeberlin Prabina ${ }^{2}$ \\ ${ }^{1}$ Department of Plant Breeding and Genetics, ${ }^{2}$ Department of Soil Science, \\ Agricultural College \& Research Institute, Killikulam, Tamil Nadu, India \\ *Corresponding author
}

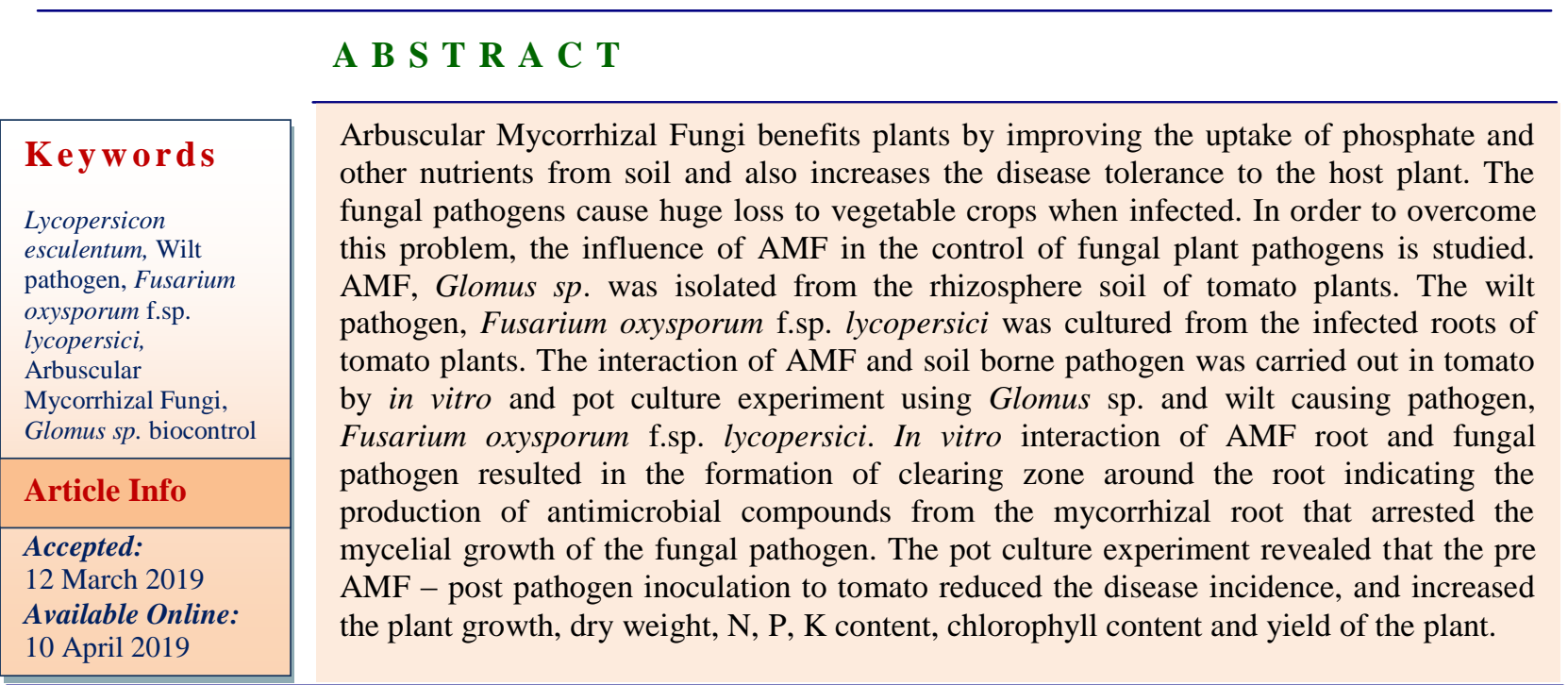

\section{Introduction}

Arbuscular Mycorrhizal Fungi is used as a potential factor in integrated plant protection. Mycelium of AMF functions as root hair and protects roots against soil borne pathogen (Azcón and Barea, 1997). It has been recognized that mycorrhizal symbiosis play a key role in nutrient cycling in the ecosystem and protects plant against environmental stress and plant diseases thereby improving the plant health (French,2017). The control of root rot diseases produced by fungi viz., Pythium, Pytophthora, Fusarium, Verticillium and Rhizoctoniais associated with AMF (Linderman, 1995). Also the increase in the absorption of nutrients, mainly phosphorus, supports the plant to withstand the attack of pathogenic microorganisms (Trotta et $a l ., 1996)$. The interaction of the AM fungus Glomus fasiculatum with a wilt-causing soil borne pathogen F.oxysporum in cowpea 
(Vigna ugniculata) reduced the severity of the disease (Sundaresan et al., 1993). Hence mycorrhizae holds its potential use in control of soil borne pathogen and the presence of AMF in soil caused a 10-20\% reduction of wilt disease in cotton (Naraghi et al., 2007). The interactions between G.intraradices and the root pathogen Fusaium oxysporum f.sp chrysanthemiina compartmentalized in vitro systemelucidated a significant negative correlation between conidia production and G.intraradices hyphae or spore concentration (Arnaud et al., 1995). The mode of action of AMF biocontrol activity is assumed to be the direct interactions between AMF and pathogens, but mycorrhiza-mediated triggering of plant defence reactions have also been proposed (Whipps, 2004). In addition, antagonism from bacteria inhabiting the mycorhizosphere has also been suggested as a possible mechanism (Budi et al., 1999). The phenomenon of AMF protecting plants from root pathogens is known from studies involving root-infecting pathogens viz., Phytophthora parasitica, Fusarium sp. and root-invading nematodes (Dodd, 2000) of tomato (Lycopersicum esculentum Mill.) and alfalfa (Medicago sativa L.) (Dehne and Schonbeck, 1979).G. mosseae induced local and systemic resistance to $P$. parasitica and was effective in reducing symptoms produced by this pathogen (Maria et al., 2002).The capability of AMF in imparting disease tolerance in tomato ( $L$. esculantum) due to Fusarium oxysporum f. sp. lycopersici is experimented.

\section{Materials and Methods}

\section{Arbuscular Mycorrhizal fungi}

AMF culture, Glomus sp was isolated from the rhizosphere soil of tomato crop by wet sieving and decanting technique (Gerdemann and Nicolson, 1963). The AMF spores isolated were identified as Glomus $s p$. according to the species description and pictures available in the INVAM website (International Culture Collection of Vesicular-Arbuscular Mycorrhizal Fungi). The AMF culture is maintained by soil trap culture method in which 1 to 3 maize seeds were placed in $10 \mathrm{~cm}$ plastic cups containing sterilized soil. Three days after the germination of maize seeds, single spore of the AMF strain was placed on fine roots or root tip of the seedling. Ten spores per seedling was inoculated in this way. After 10 days of inoculation the seedlings were transferred to pots containing sterilized soil. The pots were maintained in a greenhouse for 3 months to develop the AMF inoculum. This AMF culture, Glomus sp. is deposited in the Department of Microbiology, AC\&RI, Madurai and used for interaction studies with Fusarium wilt pathogen in tomato plants.

\section{Fungal pathogen}

The wilt pathogen, Fusarium oxysporumwas isolated from tomato variety, PKM-1 showing typical wilt symptom. The isolate was purified in Potato Dextrose Agar (PDA) medium by single hyphal tip method (Rangaswamy, 1972) and maintained on (PDA) at $30^{\circ} \mathrm{C}$.

\section{Laboratory assay to study the interaction of AMF and root pathogen}

The antagonistic effect of the mycorrhizal fungus, Glomus sp. was tested against Fusarium oxysporum f. sp. lycopersici by dual culture technique. The plain agar was prepared by adding $20 \mathrm{~g}$ of agar into 1litre of distilled water and autoclaved at $15 \mathrm{lb}$ pressure for 20 minutes. The mycorrhizal maize roots of $2 \mathrm{~cm}$ length were washed in $0.05 \%$ Tween 20 solution, soaked in $2 \%$ chloramines $\mathrm{T}$ solution for 20 minutes and rinsed thrice in sterile distilled water. The root pieces were subsequently rinsed in $100 \mathrm{mg} / \mathrm{l}$ 
gentamycin antibiotic solution. Then the root pieces were washed thrice in sterile water. Thus surface sterilized root bit was placed at the center of one half of the petriplate containing $15 \mathrm{ml}$ of plain agar medium under aseptic conditions. A loopful of fungal pathogen was placed at the center of the other half of the petriplate. The petriplate was incubated in the inverted position at room temperature for the fungal growth. The following treatments was used for the lab assay of AMF-pathogen interaction.

T1 - $\quad$ AMF, Glomus sp. uncolonized root + Fusarium oxysporum

T2 - AMF, Glomus sp. colonized root + Fusarium oxysporum

The formation of clearing zone around the AMF, Glomus sp. colonized root was examined.

Pot culture experiment to study the interaction of $\mathrm{AMF}$ and root pathogen

The interaction of AMF, Glomus sp. with soil borne pathogen, Fusarium oxysporum f.sp. lycopersici in tomato (L. esculantum) was studied in pot culture experiment.

Seeds

Seeds of tomato (L. esculantum) var. PKM-1 were obtained from Department of Olericulture, Horticultural College and Research Institute, Periyakulam.

\section{AMF Inoculant}

The AMF culture, Glomus sp. was isolated from tomato rhizosphere soil and multipliedin maize roots. The culture was maintained in the Department of Microbiology, AC\&RI, Madurai and the inoculum contained spore population of 200 spores / $50 \mathrm{~g}$ of soil. The AMF inoculum of $50 \mathrm{~g}$ was spread $2.5 \mathrm{~cm}$ below the soil surface at the time of treatment.

\section{Preparation of root pathogens}

Fusarium oxysporum f. sp. lycopersici was isolated from diseased tomato roots and maintained on Potato Dextrose Agar (PDA). The isolate of Fusarium oxysporum f. sp. lycopersici was multiplied on sand maize medium containing sand and ground maize grains mixed in the ratio of $19: 1$, moistened and autoclaved in saline bottles at $15 \mathrm{lb} / \mathrm{inch}^{2}$ pressure for two hours and incubated at $28 \pm 2^{\circ} \mathrm{C}$ for 21 days. This sand maize medium containing the pathogen at five percent level was mixed with sterile soil and filled in earthen pots of $30 \mathrm{~cm}$ height. The germination percentage on $7^{\text {th }}$ day after sowing and the disease incidence on $45^{\text {th }}$ day after sowing were assessed.

\section{Seeds and Sowing}

The seeds of tomato were surface sterilized with $0.1 \% \quad \mathrm{HgCl}_{2}$ for three minutes and washed three times successively in sterile distilled water and 10 sterilized seeds were sown in pots.

After germination, only 3 plants were maintained in each pot.

\section{Design and Treatment}

Six treatments with three replications were arranged in completely randomized block design.

T1 Control - Uninoculated.

T2 Pathogen- Fusarium oxysporum f. sp. lycopersici inoculation at the time of sowing T3 Arbuscular Mycorrhizal Fungi, Glomus sp.inoculation at the time of sowing.

T4 Simultaneous inoculation of AMF and Pathogen at the time of sowing

T5 Pre AMF inoculation at the time of sowing; Post Pathogen inoculation on $7^{\text {th }}$ day after inoculation of AMF

T6 Pre Pathogen inoculation at the time of sowing; Post AMF Inoculation on $7^{\text {th }}$ day after inoculation of Pathogen. 


\section{Experimental observation}

The plant growth biometric observation viz., dry weight / plant, fruit yield/plant, disease incidence, germination percentage and AMF spore count were recorded. The total chlorophyll content of the leaf sample was estimated following the method described by Mahadevan and Sridhar (1986). The plant analysis was done in the plant samples collected at flowering stage, dried at $60^{\circ} \mathrm{C}$ for 3 days in a hot air oven and ground in a Wiley mill to pass through a 20-mesh sieve. The nitrogen content of the plant samples was analyzed by microkjeldhal method (Humphries, 1956), phosphorus content by Vandomolybdate yellow colour method (Jackson, 1973) and potassium content by flame photometry (Jackson, 1973).

\section{Results and Discussion}

\section{Isolation of AMF strains}

The spore shape and colour of the isolated AMF, Glomus sp. was found to be globose to sub globose and pale yellow colour (Plate.1). The Glomus spores have a spore wall and all layers originating from the wall of the subtending hyphae, with a variable number of layers (1-4). No flexible inner walls are formed. The spore wall is not continuous, with a pore at the subtending hyphae which may or may not be occluded. The AMF Glomussp. was cultured by soil trap culture method in pot culture with maize as host plant. The AMF Glomus sp. spore count was 385 spores / $100 \mathrm{~g}$ of soil and root infection percentage was $80 \%$ in soil trap culture (Plate 2 and 3$)$.

\section{Isolation of soil borne pathogen from tomato}

The pathogenic fungi, Fusarium oxysporum $\mathrm{f}$. sp. lycopersici was isolated from wilt affected tomato. The fungal characteristics were the presence of micro and macro conidia and septate hyphae (Plate 4).

\section{In vitro interaction of $\mathrm{AMF}$ and soil borne pathogen}

In vitro interaction of $\mathrm{AMF}$ Glomus sp. and fungal pathogen Fusarium oxysporum f. sp. lycopersici in tomato resulted in the formation of clearing zone of $1.5 \mathrm{~cm}$ around the mycorrhizal root. The zone was observed after twelve days of inoculation. In case of non- mycorrhizal root and fungal pathogen interaction, clearing zone was not observed around the root (Plate.5\&6).

\section{Interaction of AMF and soil borne pathogen Fusarium oxysporum f. sp. lycopersici in tomato under pot culture condition}

The germination percentage was $93.8 \%$ in AMF alone inoculated seeds followed by pre AMF- post pathogen inoculated plants. AMF spore count was 165.4 spores per $100 \mathrm{~g}$ of soil in $\mathrm{AMF}$ inoculated tomato. Also the AMF inoculated plants showed no disease incidence. Disease incidence percentage was $17.7 \%$ in pre AMF - post pathogen inoculated plants and $24.6 \%$ in simultaneous inoculation of AMF and pathogen. The tomato plants inoculated with AMF alone recorded a dry weight of $29.6 \mathrm{~g}$ at flowering stage. Pre AMF post pathogen inoculation recorded $27.1 \mathrm{~g}$ as against $15.3 \mathrm{~g}$ in pathogen alone inoculated. Pre-pathogen and post AMF inoculation recorded a plant dry weight of $17.3 \mathrm{~g}$ which was on par with pathogen alone inoculated plant of $15.3 \mathrm{~g}$. The maximum chlorophyll content of $2.7 \mathrm{mg} / \mathrm{g}$ was recorded in AMF alone treated plants and $1.2 \mathrm{mg} / \mathrm{g}$ was found in pathogen alone treated plants followed by pre pathogen - post AMF treated plants.

The total nitrogen content was $1.89 \%$ due to AMF inoculation. The total phosphorus content was maximum in AMF alone 
inoculated plant followed by pre AMF - post pathogen inoculated plants. The total phosphorus content was minimum in pathogen alone inoculated plant followed by pre-pathogen post AMF inoculated plants. The plants that received the mycorrhizal inoculum showed highest potassium content of $2.25 \%$.

The yield per plant inoculated with mycorrhiza alone was 42.7 fruits/ plant and minimum yield of 20.7 fruits / plant was found in plants inoculated with pathogen alone. Among the interaction between AMF and pathogen, pre AMF-post pathogen registered more yield of 36.2 fruits/ plant (Table 1).

The beneficial effects of AM fungus on the growth of various crop plants have been well documented. AM associations, in general, can reduce or even suppress damage caused by soil borne plant pathogen (Jalaluddin et al., 2008). Since AM fungus are established in the roots of host plants, it can primarily reduce the diseases caused by soil-borne pathogens (Dehne, 1982) and mycorrhizae have been suggested as biocontrol agents (Ryan and Graham, 2002). The isolation and maintenance of AMF Glomus sp. MDU2 isolate was done by culturing in soil trap culture method using maize seedlings. After infection of the maize roots by these methods, the seedlings were transferred to pots containing sterilized soil and the AMF spores were allowed to multiply. Manfred et al., (2006) used Glomus mosseae and Glomus intraradices to infect the roots of maize and Sharif et al., (2006) studied the infection percentage of AMF in wheat and maize.

Fusarium oxysporum is a threatening fungal pathogen causing wilt disease in many crops. Wilt causing pathogen in tomato, Fusarium oxysporum f.sp. lycopersici was isolated from diseased plants. Resi et al., (2005) found seven isolates of Fusarium oxysporum f.sp. lycopercisi from tomato crops distributed all over Brazil.Trichoderma harzianum and Arbuscular mycorrhizal fungi (AMF) were able to control the wilt pathogen, Fusarium oxysporum f. sp. lycopersici in tomato seedlings (Mwangi et al., 2011; Sandani and Weerahewa, 2018).

\section{In vitro interaction of $\mathrm{AMF}$ and soil borne pathogen}

In vitro interaction between arbuscular mycorrhizal fungal root and fungal pathogen resulted in the reduction of mycelial growth ofthe fungal pathogen, Fusarium oxysporum f.sp. lycopersici of tomato. This elucidated the mode of biocontrol activity by AMF to be the direct interactions between AMF and pathogens. Mycorrhiza-mediated triggering of plant defence reactions have also been proposed (Manila and Nelson, 2014; Nasrin et al., 2018).

Interaction of AMF, Glomus sp. and soil borne pathogen Fusarium oxysporum f.sp. lycopersici in tomato

AMF, when inoculated either after pathogen inoculation or simultaneously with pathogen, the degree of growth increment was less compared to plants inoculated with AMF alone. The presence of AMF in soil caused a $10-20 \%$ reduction of wilt diseases in cotton (Naraghi et al., 2007). The culture filtrate of Rhizobium spp. and arbuscular mycorrhizal fungus act as potential biological control agents against root rot fungal diseases of Albizzialebbeck (Kaushik and Kaushik, 1995). AMF and pathogen interaction in nursery stage of tomato

AMF inoculation to soil before sowing induced seed germination at a faster rate and increased the germination percentage and also produced tallest seedlings. The AMF 
inoculated plant produced more number of roots and higher dry weight of plant in the nursery. Thomson et al., (1996) observed that the mycorrhizal tomato seedlings exhibited significantly higher dry matter than nonmycorrhizal plants. The arbuscular mycorrhizal inoculation in pepper seedlings increased the dry matter of the plant (Turkmen et al., 2005).

\section{AMF and root pathogen interaction on the root colonization percentage and Disease incidence percentage of tomato}

AMF have been shown to increase resistance to root-infecting pathogenic fungi e.g. Phytophthora parasitica or Fusarium spp. and root invading nematodes. Cordier et al., (1996) however, provided evidence for the benefits of pre-inoculation of plants with an AM fungus and showed bioprotection against P.nicotinae var. parasitica via localized and induced systemic resistance in mycorrhizal plants. An attempt to drive a relationship between AMF colonization and pathogen disease incidence percentage revealed the existence of a negative correlation between the two components. This indicated that AMF acted antagonistically to counteract the presence of pathogen resulting in the suppression of disease incidence percentage. The exact mechanism of suppression of pathogen by mycorrhizal fungus is not known.

Kapoor (2008) suggested that Glomus macrocarpum and Glomus fasciculatum inoculation increased growth and phenol concentration that were capable of imparting disease tolerance to Fusarium oxysporum $\mathrm{f}$. sp. lycopersici in tomato.

\section{Influence of AMF on the growth of tomato}

AMF alone inoculated plant recorded the maximum dry weight of $29.6 \mathrm{~g}$ per plant.
Among the interaction between the AMF and pathogen, in the pre AMF inoculated plant, dry weight was maximum followed by simultaneous inoculation of AMF and pathogen.

Bayozen and Yildiz (2009) determined the mycorrhizal interaction with pathogen Rhizoctonia solani and observed that the pathogenicity was reduced in AM fungus inoculated plants.

\section{Influence of AMF on the nutrition of tomato}

AM fungal inoculation increased the total chlorophyll content of the plant significantly. Druva et al., (2008) also observed that the mycorrhizalinoculated marsh plant improved its photosynthetic performance and also the inoculation with Glomus epigaeum increased the chlorophyll content in black gram and also increased the $\mathrm{N}, \mathrm{P}$ and $\mathrm{K}$ content (Umadevi and Sitaramaiah, 1998).

The N, P and $\mathrm{K}$ contents were very high in AMF alone inoculated plant. Among the interaction between the AMF and pathogen, the pre AMF inoculated plant showed maximum $\mathrm{N}, \mathrm{P}$ and $\mathrm{K}$ content followed by simultaneous inoculation of AMF and pathogen. Pre pathogen treated plants recorded minimum $\mathrm{N}, \mathrm{P}$ and $\mathrm{K}$ content. The inoculation of AM fungus to pepper seedlings increased the total nitrogen content in the plants (Turkmen et al., 2005).

Albizzia plants treated with Glomus mosseae recorded higher nitrogen concentration (Kaushik and Kaushik, 1995). Arbuscular mycorrhizal fungi, Glomus intraradiaces improved the phosphorus efficiency of plants (Seoud,2008). Dalbergia sissoo inoculated with G.fasciculatum increased the K uptake (Manoharachary et al., 2008). 
Table.1 Interaction effect of AMF and soil borne pathogen Fusarium oxysporum f.sp. lycopersici in tomato seedlings under pot culture condition

\begin{tabular}{|c|c|c|c|c|c|c|c|c|c|c|}
\hline S. No & Treatments & $\begin{array}{l}\text { Germination } \\
\text { percentage } \\
\text { on } 7^{\text {th }} \text { day } \\
\text { after sowing }\end{array}$ & $\begin{array}{l}\text { AMF } \\
\text { Spores/ } \\
100 g \text { of } \\
\text { soil }\end{array}$ & $\begin{array}{c}\text { Disease } \\
\text { incidence on } \\
45^{\text {th }} \text { day after } \\
\text { sowing }(\%)\end{array}$ & $\begin{array}{c}\text { Dry } \\
\text { weight } \\
\text { (g/plant) }\end{array}$ & $\begin{array}{l}\text { Chlorophyll } \\
\text { content } \\
(\mathrm{mg} / \mathrm{g})\end{array}$ & $\begin{array}{l}\text { Total } \\
\text { Nitrogen } \\
(\%)\end{array}$ & $\begin{array}{l}\text { Total } \\
\text { phosphorus } \\
(\%)\end{array}$ & $\begin{array}{l}\text { Total } \\
\text { potassiu } \\
\mathrm{m}(\%)\end{array}$ & $\begin{array}{l}\text { Yield (no.of } \\
\text { fruits/plant) }\end{array}$ \\
\hline 1. & Uninoculated - control & 66.6 & 0.0 & 12.0 & 21.3 & 1.7 & 1.49 & 0.38 & 1.67 & 26.6 \\
\hline 2. & $\begin{array}{l}\text { Pathogen Fusarium } \\
\text { oxysporum f.sp. lycopersici } \\
\text { alone }\end{array}$ & 53.3 & 0.0 & 72.4 & 15.3 & 1.2 & 1.34 & 0.21 & 1.21 & 20.7 \\
\hline 3. & AMF inoculated alone & 93.8 & 165.4 & 0.0 & 29.6 & 2.7 & 1.89 & 0.50 & 2.25 & 42.7 \\
\hline 4. & $\begin{array}{l}\text { Pre AMF - Post Pathogen } \\
\text { (15 days before inoculation) }\end{array}$ & 86.6 & 130.9 & 17.7 & 27.1 & 2.2 & 1.67 & 0.46 & 1.85 & 36.2 \\
\hline 5. & $\begin{array}{l}\text { Pre pathogen - Post AMF } \\
\text { ( } 7 \text { days before inoculation) }\end{array}$ & 60.0 & 50.7 & 51.2 & 17.3 & 1.3 & 1.43 & 0.24 & 1.38 & 22.7 \\
\hline \multirow[t]{2}{*}{6.} & $\begin{array}{l}\text { Simultaneous inoculation of } \\
\text { AMF and Pathogen }\end{array}$ & 76.6 & 80.6 & 24.6 & 23.9 & 1.9 & 1.63 & 0.41 & 1.79 & 30.0 \\
\hline & SEd & 3.0 & 3.8 & 2.0 & 0.7 & 0.0 & 0.04 & 0.01 & 0.09 & 1.2 \\
\hline
\end{tabular}


Plate.1\&2 Spore of Glomus sp. from rhizosphere soil of tomato \& Multiplication of Glomus sp. by soil trap method in maize roots
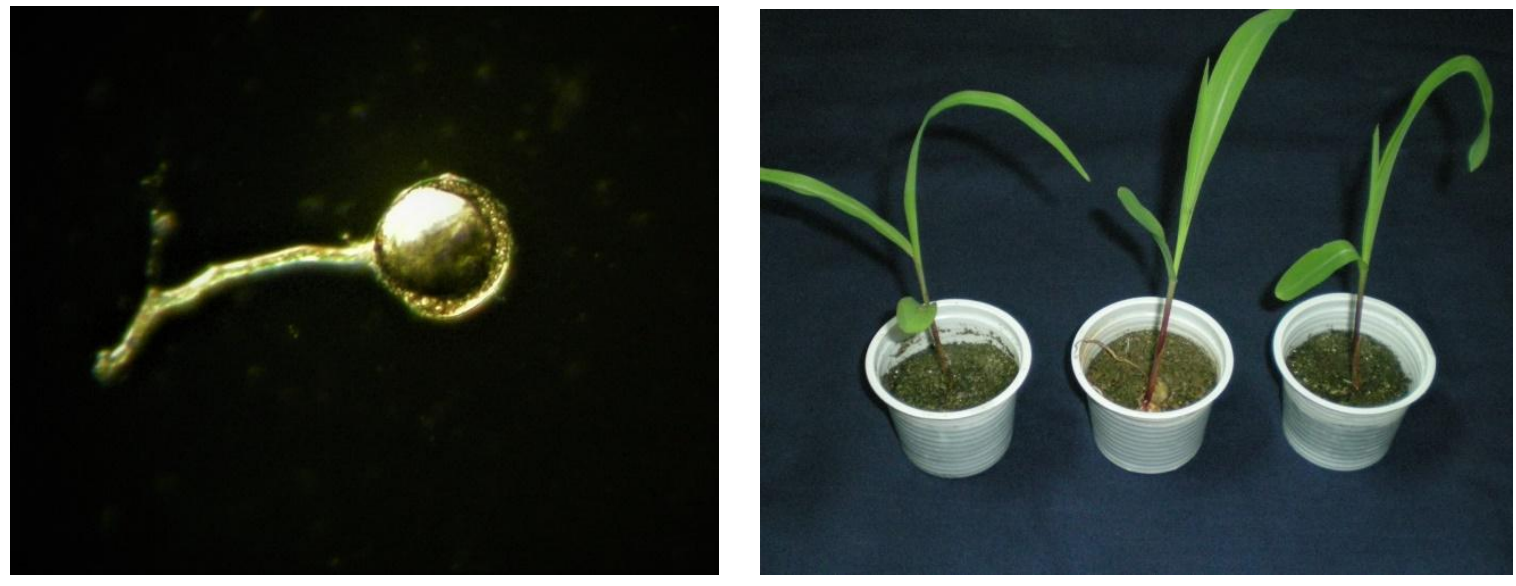

Plate.3\&4 AMF, Glomus sp. infection in maize roots for multiplication as inoculum \& Fungal colony of the wilt pathogen, Fusarium oxysporumf.sp.lycopersici
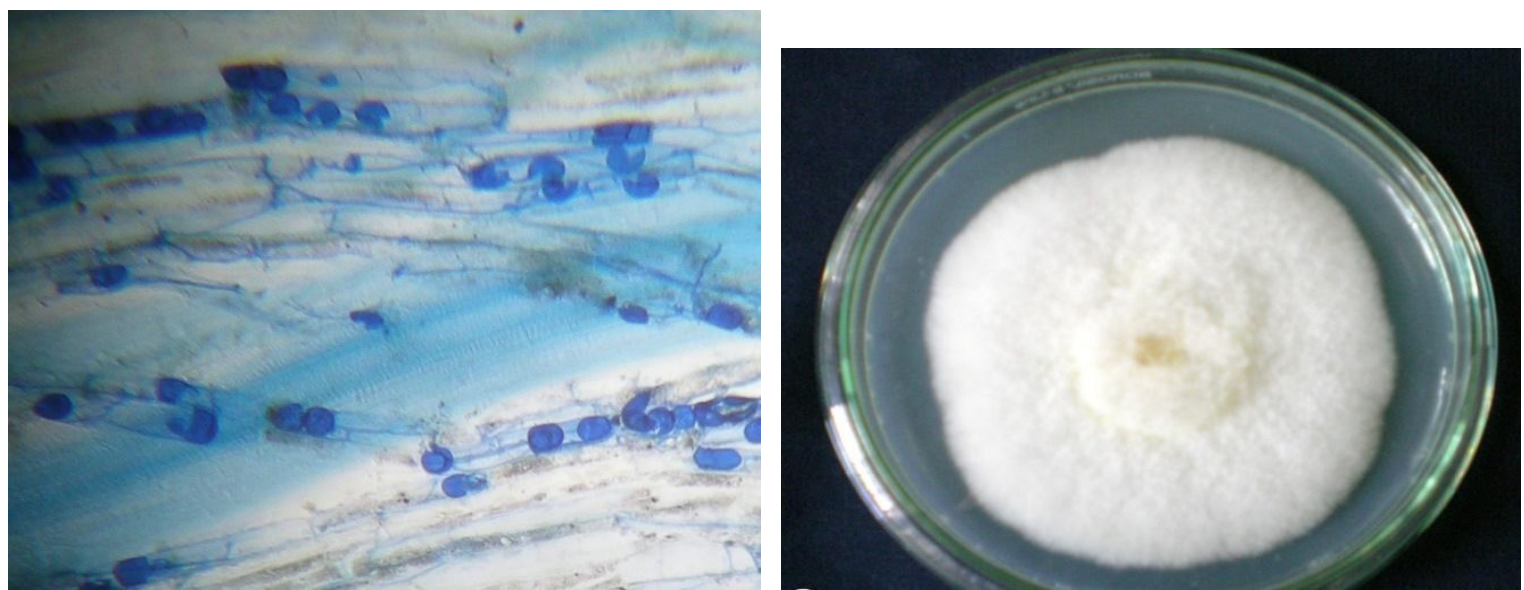

Plate.5\&6 In vitro interaction between AMF un-colonized maize root and Fusarium wilt pathogen - no clearing zone formed around the root \& In vitro interaction between AMF colonized maize root and Fusarium wilt pathogen in vitroby dual culture - clearing zone formed around the root
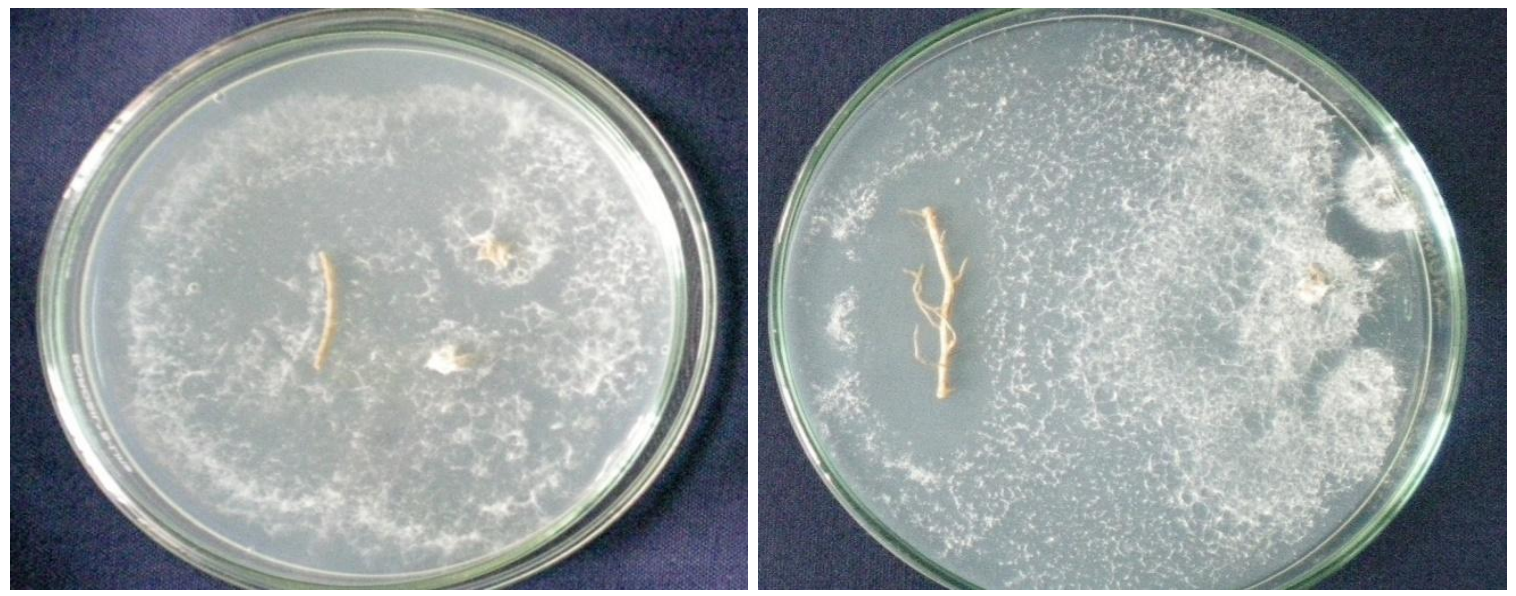


\section{Influence of AMF on the yield of tomato}

The highest yield was recorded in the AMF inoculated plants and those inoculated with pathogen (either pre or post AMF inoculation) registered a significantly lower yield. Glomus fasiculatum inoculation in soilless grown tomato plants increased the growth, yield, fruit properties and nutrient uptake (Dasgan et al.,2008) and similar observation is also made in many other crops (Haque and Matsubara,2018). The pot culture experiment revealed the interaction between AMF and soil borne pathogen Fusarium oxysporum f. sp. lycopersici of tomato. AMF inoculation was found to reduce the disease incidence percentage. Pre inoculation of AMF followed by pathogen reduced the disease infection better than simultaneous application of pathogen. The mycorrhizal inoculation showed vigorous growth of tomato seedlings and increased the crop nutrition and yield.AM fungi also interact with most crop plants including cereals, vegetables, and fruit trees, therefore, they receive increasing attention for their potential use in sustainable agriculture (Chen et al., 2018).

\section{References}

Arnaud, M., C.Hamel, M.Caron and J.A. Fortin. 1995. Inhibition of Pythium ultimum in roots and growth substrate of mycorrhizal Tagetespatula colonized with Glomus intraradices. Can. J. of Pl. Pathol.16: 187-194.

Azcon, A.C. and J. M. Barea. 1997. Arbuscular mycorrhizas and biological control of soil borne plant pathogens: an overview of the mechanisms involved. Mycorrhiza,6: 457-464.

Bayozen, A. and A. Yildiz. 2009. Determination of mycorrhizal interactions and pathogenicity of Rhizoctonia solani isolated from strawberry and Xanthium strumarium.
Turk. J. Biol., 33: 53-57.

Budi, S.W., D.T. Van, G. Martinotti and S. Gianiinazzi. 1999. Isolation from the Sorghum bicolor mycorhizosphere of a bacterium compatible with arbuscular mycorrhiza development and antagonistic towards soil borne fungal pathogens. Applied and Environmental Microbiology, 65: 5148-5150.

Chen,M, M. Arato, L. Borghi, E. Nouri, and D. Reinhardt. 2001. Beneficial Services of Arbuscular Mycorrhizal Fungi From Ecology to Application. Front Plant Sci.9: 1270.

Cordier, C., S. Gianinazzi and V. Gianinazzipearson. 1996. Colonization patterns of root tissues by Phytophthora nicotinae var. parasitica to reduce disease in mycorrhizal plants. Plant and soil, 185: 223-232.

Dehne, H.W. 1982. Interaction between vesicular-arbuscular mycorrhizal fungi and plant pathogens. Phytopathology, 72: 1115-1119.

Dehne, H.W. and F. Schonbeck. 1979. Untersuchungenzum Einfluss der endotrophen Mycorrhiza auf pflanzenkrankheiten I. Ausbreitung von Fusarium oxysporum f.sp lycopersici in Tomaten. chezeitschrift., 95:105-110.

Phytopathologis.

Druva, L.L., A. Karlsons, A. Osvalde, J.Necajeva and G. Levish. 2008. Photosynthetic performance and mycorrhizal symbiosis of a coastal marsh plant, Glaux maritime, in conditions of fluctuating soil salinity. Acta Universitatis Latviensis., 745: 155164.

French.2017. Engineering Mycorrhizal Symbioses to Alter Plant Metabolism and Improve Crop Health. Frontiers in Microbiology.8: 1403

Gerdemann, J.W. and T.H. Nicolson. 1963. Spores of mycorrhizal Endogene species extracted from soil by wet 
sieving and decanting. Trans. $B r$. Mycol. Soc., 46: 235-244.

Haque, S.I. and Y. Matsubara. 2018. CrossProtection to Salt Stress and Fusarium Wilt with the Alleviation of Oxidative Stress in Mycorrhizal Strawberry Plants. Environmental Control in Biology.56 (4): 187-192.

Humphries, E.C. 1956. Mineral composition and ash analysis .In: Modern methods of plant analysis. Vol.I (eds., K. Peach and M.V. Trecy). Springer Verlag Berlin, pp. 468-502.

Jackson, M.L. 1973. Soil chemical analysis. Prentice Hall of India.Pvt. Ltd., New Delhi. p. 498.

Jalaluddin, M., H. Maria and S.E. Muhammed. 2008. Selection and application of a VAM-fungus for promoting growth and resistance to charcoal rot disease of sunflower var. Helico-250. Pak. J. Bot., 40(3): 13131318.

Kapoor, R. 2008. Induced resistance in mycorrhizal tomato is correlated to concentration of Jasmonic acid. Online Journal Biological Sciences, 8(3): 4956.

Kaushik, J.C. and N. Kaushik. 1995. Interaction between vesicular arbuscular mycorrhizal fungi and Rhizobium and their influence on Albizzialebbeck. In: Mycorrhiza-biofertilizers for the future. (eds., AlokAdhleya and Sujan Singh). Proc. of the third National conf. on Mycorrhiza. pp. 212-215.

Linderman, R.G. 1995. Role of VAM fungi in biocontrol. In: Mycorrhizae and Plant Health. (eds., F.L.Pfleger and R.G. Linderman). St. Paul: APS Press. pp. 125.

Mahadevan, A. and R. Sridhar. 1986. Methods in physiological plant pathology. Sivakami publication, Madras, p.328.

Manfred, J.G., P. David, R. Jana and V.
Miroslall.2006. Effect of inoculation with soil yeasts on mycorrhizal symbiosis of maize. Pedobiologia, 50: 341-345

Manila,S and R. Nelson. 2014. Biochemical changes induced in tomato as a result of arbuscular mycorrhizal fungal colonization and tomato wilt pathogen infection. Asian Journal of Plant Science and Research, 2014, 4(1):6268.

Manoharachary, C., P. Ameeta, I.K. Kunwar and S. Vishnuvardhan Reddy. 2008. Arbuscular Mycorrhizal Fungi in relation to plant growth in Dalbergiasissoo. J. Mycol. Pl. Pathol., 38:97-101.

Maria, J.P., C. Coridier, D.G. Eliane, G. Silvio, M.B. Jose and A.A. Concepcion. 2002. Localized versus systemic effect of arbuscular mycorrhizal fungi on defence responses to Phytophthora infection in tomato plants. Journal of Experimental Botany, 531(368): 525534.

Mwangi, M.W, E.O. Monda, S.A. Okoth and J.M.Jefwa. 2011. Inoculation of tomato seedlings with Trichoderma Harzianum and Arbuscular Mycorrhizal Fungi and their effect on growth and control of wilt in tomato seedlings. Brazilian Journal of Microbiology. 42(2): 508513.

Naraghi, L., H.Z. Maivan, A.Heydari and H.A. Azad. 2007. Investigation of the effect of heating, vesicular arbuscular mycorrhiza and thermophilic fungus on cotton wilt disease. Pakistan. J. of Bio. Sci., 10(10): 1596-1603.

Nasrin.L, S. Podder and MR Mahmud. 2018. Investigation of Potential Biological Control of Fusarium Oxysporum f.sp. Lycopersici by Plant Extracts, Antagonistic sp. and Chemical Elicitors In Vitro. Fungal Genomics and Biology. 2018, 8:1. 
Rangaswamy, G.1972. Diseases of crop plants in India. Prentice Hall of India Pvt. Ltd., New Delhi, p.520.

Resi, A., H. Costa, L. S. Boiteux 1 and C. A. Lopes. 2005. First Report of Fusarium oxysporumf. sp. lycopersici Race 3 on Tomato in Brazil. Fitopatol.Bras., 30(4): 426-428.

Ryan, M.H. and J.H. Graham.2002. Is there a role for arbuscular mycorrhizal fungi in production agriculture? Plant and Soil, 244:263-271.

Sandani H. B. P. and Weerahewa H. L. D. 2018. Wilt diseases of tomato (Lycopersicum esculentum) and chilli (Capsium annum) and their management strategies: emphasis on the strategies employed in Srilanka: A review. Sri Lankan J. Biol. 2018, 3 (2): 24-43.

Seoud, A.E. 2008. Phosphorus efficiency of Tagetus plant inoculated with two AMF strains. Australian Journal of Basic and Applied Sciences, 2(2): 234-242.

Sharif, M., M.S. Sarir and Nasrullah.2006.Field evaluation of arbuscular mycorrhizal fungi in wheatmaize cropping system in Hazara division of North West Frontier Province. Pakistan Journal of Biological Sciences, 9(3): 487-492.

Sundaresan, P., N.U. Raja and P. Gunasekaran. 1993. Induction and accumulation of phytoalexins in cowpea roots infected with a mycorrhizal fungus Glomus fasiculatum and their resistance to Fusarium wilt diseases. $J$. of Biosci., 18: 291-301.

Thomson, T.E., S.Manian and K. Udaiyan. 1996. Interaction of multiple VAM fungal species on root colonization, plant growth and nutrient status of tomato seedlings. Agriculture Ecosystems and Environment, 59: 6368.

Trotta, A., G.C. Varese, E. Gnavi, A. Fusconi, S. Sampo and G. Berta. 1996 Interactions between the soil borne root pathogen Phytophthora nicotinae var. parasitica and the arbuscualr mycorrhizal fungus Glomus mosseae in tomato plants. Plant and soil.185: 199209.

Turkmen, O., D. Semra, S.Suat and D. Atilla. 2005. Effect of AMF and humic acid on the seedling development and nutrient content of pepper grown under saline soil conditions. J. of Bio.Sci.,5(5): 568574.

Umadevi, G. and K. Sitaramaiah. 1998. Effect of super phosphate and rock phosphate as a source of $\mathrm{P}$ in combination with endomycorrhizal fungi on growth and chemical composition of maize. $J$. Mycol. Pl.Pathol., 28(2): 154-160.

Whipps, J.M. 2004. Prospects and limitations for mycorrhizas in biocontrol of root pathogens. Can. J. of Bot., 82: 11271198.

\section{How to cite this article:}

Merina Prem Kumari, S. and Jeberlin Prabina, B. 2019. Protection of Tomato, Lycopersicon esculentum from Wilt Pathogen, Fusarium oxysporum f.sp. lycopersici by Arbuscular Mycorrhizal Fungi, Glomus sp. Int.J.Curr.Microbiol.App.Sci. 8(04): 1368-1378. doi: https://doi.org/10.20546/ijcmas.2019.804.159 